\title{
PENGGUNAAN MEDIA PEMBELAJARAN BERBASIS SOFTWARE MULTISIM BERBANTUAN MODEL DISCOVERY LEARNING UNTUK MENCAPAI HASIL BELAJAR FISIKA MATERI RANGKAIAN LISTRIK PADA SISWA KELAS IX SMP NEGERI 11 AMBON
}

\author{
Noke Kesaulya \\ Program Studi Pendidikan Fisika FKIP Universitas Pattimura \\ noke.kesaulya1977@gmail.com
}

\begin{abstract}
ABSTRAK. Penelitian ini bertujuan untuk mengetahui pencapaian hasil belajar siswa dengan menggunakan media pembelajaran berbasis software multisim berbantuan model discovery learning. Model discovery learning memiliki enam tahapan dalam pembelajaran yaitu : 1) Pemberian stimulus, 2) Mengindentifikasi masalah, 3) Mengumpulkan data, 4) Mengolah data, 5) memverifikasi data, 6) Menyimpulkan. Tipe Penelitian yang digunakan dalam penelitian ini adalah tipe penelitian deskriptif. Subjek penelitian ini adalah siswa kelas IX SMP Negeri 11 Ambon yang berjumlah 19 orang. Dari hasil penelitian diperoleh, kemampuan awal siswa kelas IX SMP Negeri 11 Ambon 100\% berada pada kualifikasi gagal dengan rata-rata skor pencapaian 10. Rata-rata kemampuan kognitif siswa 81.19 berada pada kualifikasi baik, rata-rata kemampuan afektif siswa 92.5 berada pada kualifikasi sangat baik, rata-rata kemampuan psikomotor siswa 87.68 berada pada kualifikasi baik. Untuk hasil tes formatif menunjukkan secara klasikal 19 siswa tuntas untuk materi rangkaian listrik dan berada pada kualifikasi cukup dengan rata-rata skor pencapaian 83.8. Rata-rata skor pencapaian nilai akhir siswa 87.13. Respon siswa selama kegiatan belajar mengajar berlangsung dengan menggunakan software multisim berbantuan model discovery learning termasuk dalam kategori sangat baik hal ini didasarkan karena peroleh nilai pada aspek afektif yang berada pada kategori sangat baik. Berdasarkan hasil penelitian yang dilakukan, maka dapat disimpulkan bahwa proses pembelajaran menggunakan media pembelajaran berbasis software multisim berbantuam model discovery learning efektif membantu siswa kelas IX SMP Negeri 11 Ambon guna mencapai hasil belajar fisika materi rangkaian listrik.
\end{abstract}

Kata Kunci: Software Multisim, Discovery Learning, Hasil Belajar, Rangkaian Listrik.

\section{Pendahuluan}

Salah satu komponen pendukung dalam pembelajaran adalah media pembelajaran. Sadiman (2007) menyatakan bahwa media pembelajaran diartikan sebagai segala bentuk dan saluran yang digunakan orang untuk menyalurkan pesan/informasi. Mereka juga menyatakan bahwa media adalah berbagai jenis komponen dalam lingkungan siswa yang dapat merangsangnya untuk belajar. Wenno (2011) mengemukakan bahwa pentingnya pemilihan media pembelajaran merupakan faktor utama dalam mengoptimalkan hasil pembelajaran. Media pembelajaran memiliki peran yang sangat penting untuk mengantarkan siswa menguasai konsep-konsep fisika dan memecahkan masalah-masalah yang berkaitan dalam kehidupan sehari-hari. Untuk memilih media yang tepat, seorang pendidik perlu mempertimbangkan berbagai landasan agar media yang dipilih benar-benar sesuai dengan tingkat pemahaman kemampuan berpikir, psikologis, dan kondisi sosial siswa. Menurut Arsyad (2007) media pembelajaran yang sesuai dengan perkembangan teknologi adalah media pembelajaran berbasis komputer. Media berbasis komputer dapat dikembangkan dalam beberapa format antara lain drills and practice, tutorial, simulation dan permainan serta discovery.

Lubis (2012) menyatakan bahwa selain media pembelajaran, penggunaan model pembelajaran juga sangat penting sehingga adanya kesinambungan antara media dan model pembelajaran yang digunakan. Pemilihan model pembelajaran harus disesuaikan dengan materi dan karakteristik siswa. Hasil pengamatan lapangan di SMP Negeri 11 ambon melalui wawancara dengan guru bidang studi fisika ditemukan bahwa dalam kegiatan belajar mengajar, 
guru masih menggunakan metode ceramah dimana proses pembelajaran masih didominasi pada guru akibatnya pembelajaran kurang memberikan kesempatan untuk siswa terlibat aktif dalam pengalaman belajarnya. Sedangkan media yang sering digunakan guru dalam proses pembelajaran adalah sebatas media cetak seperti buku teks. Untuk media berbasis software, guru hanya menggunakan power point untuk menunjukkan gambar-gambar kepada siswa.

SMP Negeri 11 Ambon memiliki satu laboratorium IPA akan tetapi kondisi dalam laboratorium belum memadai. Alat-alat praktikum fisika pada mata pelajaran kelistrikan tidaklah lengkap sehingga siswa hanya bisa belajar sebatas teori saja. Guru juga mengatakan bahwa sekarang masih dalam proses untuk melengkapi kekurangan yang ada pada laboratorium tetapi tidak bisa sekaligus melainkan secara bertahap, hal ini membuat para siswa harus bisa menahan keinginan mereka untuk melakukan praktikum sedangkan hasil belajar fisika pada materi rangkaian listrik sendiri belum tercapai dengan maksimal. Siswa masih kesulitan dalam pemahaman konsep dan menghitung, fakta ini dibuktikan dengan siswa yang masih salah menafsirkan perbedaan antara karakteristik rangkaian listrik dengan jenis-jenis rangkaian listrik dan juga masih lambat di bagian perhitungan seperti menghitung kuat arus pada rangkaian seri, paralel, dan campuran.

Media yang dapat digunakan sebagai upaya untuk membantu memecahkan masalah di atas adalah media simulasi berbasis software. Selain mudah didapatkan, media software dapat digunakan sebagai alternatif untuk sekolah-sekolah yang sarana prasarana belum memadai, salah satunya menggunakan multisim. Shema (2004) menyatakan bahwa multisim adalah program capture dan simulasi skema yang dirancang untuk entri skematis, simulasi, dan pengisian ke tahap downstage, seperti layout PCB, termasuk juga kemampuan simulasi analog/digital campuran, dan ko-simulasi mikrokontroler. Multisim adalah operasi klik dan drag yang membuat, mengedit sebuah rangkaian secara mudah dan cepat. Program ini penuh dengan skematik yang terintegrasi, simulasi dan logika pemograman.

Di samping itu juga salah satu model pembelajaran yang dapat digunakan untuk menciptakan kinerja siswa adalah dengan model discovery learning. Model ini mempunyai keunggulan yaitu memberikan kesempatan kepada siswa untuk menyikapi atau mencari tahu tentang suatu permasalahan atau sesuatu yang sebenarnya ada, namun belum mengemukakan dan menemukan solusinya berdasarkan hasil pengolahan informasi yang dicari dan dikumpulkanya sendiri, sehingga siswa memiliki pengetahuan baru yang dapat digunakan dalam memecahkan persoalan yang relevan dalam kehidupan sehari-hari (Kemendikbud, 2017).

Setelah melihat cara kerja software multisim dan keunggulan yang terdapat pada model pembelajaran discovery learning serta melihat kondisi pembelajaran fisika di SMP Negeri 11 Ambon, maka peneliti perlu melakukan penelitian tentang penggunaan media pembelajaran berbasis software multisim berbantuan model discovery learning untuk mencapai hasil belajar fisika materi rangkaian listrik pada siswa kelas IX SMP Negeri 11 Ambon.

\section{Metode}

Penelitian ini menggunakan tipe penelitian deskriptif kuantitatif dan kualitatif. Penelitian memfokuskan pada pencapaian hasil belajar siswa kelas IX SMP Negeri 11 Ambon pada materi rangkaian listrik menggunakan media pembelajaran berbasis software multisim berbantuan model discovery learning.

$$
\mathrm{O}_{1} \quad \mathrm{X} \quad \mathrm{O}_{2}
$$

\section{Gambar 1. Rancangan Desain Penelitian}

Desain penelitian yang digunakan adalah one group pretest and posttest design. Dalam desain ini observasi dilakukan sebanyak dua kali yaitu sebelum eksperimen dan sesudah eksperimen. Observasi yang dilakukan sebelum eksperimen $\left(\mathrm{O}_{1}\right)$ disebut pretes dan osbervasi sesudah eksperimen $\left(\mathrm{O}_{2}\right)$ disebut postes.

Penelitian ini membawa siswa untuk mengetahui secara mandiri konsep atau prinsip dari materi rangkaian listrik dengan didukung oleh media pembelajaran berbasis software multisim berbantuan model pembelajaran 
discovery learning. Model pembelajaran discovery learning memberikan kesempatan kepada siswa untuk mencari tahu tentang suatu permasalahan atau sesuatu yang sebenarnya dan menemukan solusinya berdasarkan hasil pengolahan informasi yang dicari dan dikumpulkannya sendiri. Untuk memperoleh data yang akurat dilakukan uji validitas (RPP, LKS, dan soal-soal tes hasil belajar) terlebih dahulu sebelum digunakan untuk mengambil data. Analisis data yang digunakan dalam penelitian ini adalah analisis data deskriptif untuk melihat tingkat penguasaan siswa terhadap materi yang diajarkan sebelum dan sesudah proses pembelajaran menggunakan software multisim berbantuan model pembelajaran discovery learning, dan pencapaian hasil belajar siswa dilihat berdasarkan nilai kognitif, afektif, psikomotor, nilai formatif dan nilai akhir (NA) siswa. Perhitungan nilai akhir siswa menurut Arikunto (2009) guru mempunyai pendapat tersendiri tentang cara penentuan nilai akhir, hasil belajar yang dipengaruhi oleh pandangan-pandangan tentang pentingnya bagian-bagian kegiatan yang dilakukan siswa. Persentase perhitungan nilai akhir siswa dihitung menggunakan persamaan NA $=20 \%$ LKS $+30 \%$ Afektif $+30 \%$ Psikomotor $+20 \%$ Nilai Formatif.

\section{Hasil Penelitian}

Hasil analisis instrumen berupa tes awal siswa pada materi rangkaian listrik sebelum diajarakan dengan software multisim berbantuan model discovery learning menunjukkan bahwa $100 \%$ siswa berada pada kualifikasi gagal dengan rata-rata tes awal 10. Nilai yang diperoleh siswa di bawah Kriteria Ketuntasan Minimal (KKM), dengan nilai terendah siswa yaitu 4,4 dan nilai tertinggi siswa 17,7.

Tabel 1. Persentase Pencapaian Siswa pada Tes Kemampuan Awal

\begin{tabular}{|c|c|c|l|}
\hline $\begin{array}{c}\text { Tingkat } \\
\text { Penguasaan }\end{array}$ & Frekuensi & Persentase (\%) & Kualifikasi \\
\hline $91-100$ & - & - & Sangat Baik \\
\hline $80-90$ & - & - & Baik \\
\hline $69-79$ & - & - & Cukup \\
\hline$<69$ & 19 & 100 & Gagal \\
\hline \multicolumn{2}{|c|}{ Rata-rata nilai tes awal siswa $=10$} & Gagal \\
\hline
\end{tabular}

\section{Deskripsi Tingkat Kemampuan Afektif Siswa}

Tingkat kemampuan aspek afektif siswa yang dinilai selama proses pembelajaran (2 kali pertemuan) meliputi: Kedisiplinan, Kemampuan menghargai pendapat teman, Keseriusan dalam bekerja selama proses belajar-mengajar berlangsung dan kemampuan bekerja sama. Nilai rata-rata aspek afektif pada pertemuan pertama dan kedua terlihat adanya kesamaan yaitu sebesar 92,5 (Tabel 2). Berdasarkan Tabel 2. menunjukkan bahwa terdapat 11 siswa (58\%) dengan kualifikasi sangat baik dan 8 siswa (42\%) dengan kualifikasi baik. Dari pertemuan pertama dan kedua pada penilaian aspek afektif menunjukkan bahwa tidak terdapat siswa yang berada pada kualifikasi gagal. Secara keseluruhan bahwa masing-masing siswa telah mencapai nilai ketuntasan yaitu 65.

Tabel 2. Persentase Pencapaian Siswa pada Penilaian Aspek Afektif

\begin{tabular}{|l|c|c|l|}
\hline $\begin{array}{l}\text { Tingkat } \\
\text { Penguasaan }\end{array}$ & Frekuensi & $\begin{array}{l}\text { Persentase } \\
(\%)\end{array}$ & Kualifikasi \\
\hline $91-100$ & 11 & 58 & Sangat Baik \\
\hline $80-90$ & 8 & 42 & Baik \\
\hline $69-79$ & - & - & Cukup \\
\hline$<69$ & - & - & Gagal \\
\hline \multicolumn{2}{|l}{ Rata-rata nilai aspek afektif $=92,5$} & Sangat Baik \\
\hline
\end{tabular}




\section{Deskripsi Tingkat Kemampuan Psikomotor Siswa}

Tingkat kemampuan aspek psikomotor siswa yang dinilai selama proses pembelajaran ( 2 kali pertemuan) meliputi: kompetensi dalam mengoperasikan multisim, keseriusan dan ketelitian dalam mengamati pengoperasian multisim, kemampuan dalam bertanya, dan kemampuan membuat kesimpulan. Nilai rata-rata pencapaian siswa dalam aspek psikomotor pada pertemuan pertama dan kedua terlihat adanya kenaikan nilai, dimana pada pertemuan pertama sebesar 86,36 dan pada pertemuan kedua sebesar 89. Rata-rata skor pencapaian siswa secara keseluruhan dalam aspek psikomotor ditunjukkan pada Tabel 3.

Tabel 3. Persentase Pencapaian Siswa pada Penilaian Aspek Psikomotor

\begin{tabular}{|c|c|c|c|}
\hline $\begin{array}{l}\text { Tingkat } \\
\text { Penguasaan }\end{array}$ & Frekuensi & $\begin{array}{c}\text { Persentase } \\
(\%)\end{array}$ & Kualifikasi \\
\hline $91-100$ & 9 & 48 & Sangat Baik \\
\hline $80-90$ & 2 & 10 & Baik \\
\hline $69-79$ & 8 & 42 & Cukup \\
\hline$<69$ & - & - & Gagal \\
\hline \multicolumn{3}{|c|}{ Rata-rata nilai aspek psikomotor $=87,68$} & Baik \\
\hline
\end{tabular}

Berdasarkan Tabel 3. Terlihat bahwa rata-rata kemampuan siswa dalam aspek psikomotor secara keseluruhan yaitu 9 siswa (48\%) dengan kualifikasi sangat baik, 2 siswa (10\%) dengan kualifikasi baik, dan 8 siswa (42\%) berada pada kualifikasi cukup. Secara keseluruhan bahwa masing-masing siswa mencapai nilai ketuntasan 69.

\section{Deskripsi Tingkat Kemampuan Kognitif Siswa}

Tingkat kemampuan aspek kognitif siswa yang dinilai selama proses pembelajaran (2 kali pertemuan) berupa: penilaian langsung pada saat siswa sedang mengoperasikan software multisim serta menjawab dengan baik dan benar pertanyaan-pertanyaan yang terdapat pada lembar kegiatan siswa (LKS). Rata-rata pencapaian siswa dalam aspek kognitif pada pertemuan pertama dan kedua adalah 81,19 yang berada pada kualifikasi baik ditunjukkan pada Tabel 4.

Tabel 4. Persentase Pencapaian Siswa pada Penilaian Aspek Kognitif

\begin{tabular}{|l|l|l|l|}
\hline $\begin{array}{l}\text { Tingkat } \\
\text { Penguasaan }\end{array}$ & Frekuensi & $\begin{array}{l}\text { Persentase } \\
(\%)\end{array}$ & Kualifikasi \\
\hline $91-100$ & 3 & 16 & Sangat Baik \\
\hline $80-90$ & 8 & 42 & Baik \\
\hline $69-79$ & 7 & 37 & Cukup \\
\hline$<69$ & 1 & 5 & Gagal \\
\hline \multicolumn{2}{|l|}{ Rata-rata nilai aspek kognitif $=81,19$} & Baik \\
\hline
\end{tabular}

Berdasarkan Tabel 4. Terlihat bahwa rata-rata kemampuan siswa dalam aspek kognitif secara keseluruhan yaitu 3 siswa (16\%) dengan kualifikasi sangat baik, 8 siswa (42\%) dengan kualifikasi baik, 7 siswa (37\%) berada pada kualifikasi cukup dan 1 siswa (5\%) berada pada kualifikasi gagal. Siswa yang termasuk dalam kategori sangat baik merupakan siswa yang berhasil dalam setiap indikator yang ada pada LKS pertama dan kedua, sementara siswa yang berada pada kualifikasi baik merupakan siswa yang pada indikator menghitung, bisa dipahami tetapi tidak dijabarkan secara detail. Begitupun siswa yang berada pada kualifikasi cukup merupakan siswa yang masih keliru dalam indikator menghitung, sementara siswa yang gagal merupakan siswa yang belum berhasil dalam indikator menghitung.

\section{Deskripsi Tingkat Penguasaan Hasil Tes Formatif Siswa}

Tes akhir (posttest) sebagai tes formatif yang diberikan kepada siswa setelah proses pembelajaran bertujuan untuk mengetahui kemampuan siswa terhadap materi yang diajarkan. Kualifikasi rata-rata skor pencapaian tes formatif siswa ditunjukkan pada Tabel 5. 
Tabel 5. Persentase Pencapaian Siswa pada Hasil Tes Formatif

\begin{tabular}{|l|l|l|l|}
\hline $\begin{array}{l}\text { Tingkat } \\
\text { Penguasaan }\end{array}$ & Frekuensi & $\begin{array}{l}\text { Persentase } \\
(\%)\end{array}$ & Kualifikasi \\
\hline $91-100$ & 5 & 26 & Sangat Baik \\
\hline $80-90$ & 9 & 48 & Baik \\
\hline $69-79$ & 4 & 21 & Cukup \\
\hline$<69$ & 1 & 5 & Gagal \\
\hline \multicolumn{2}{|l|}{ Rata-rata nilai tes formatif $=83,8$} & Baik \\
\hline
\end{tabular}

Tabel 5. Menunjukkan bahwa terdapat 5 siswa (26\%) berada pada kualifikasi sangat baik, 9 siswa (48\%) berada pada kualifikasi baik, 4 siswa (21\%) berada pada kualifikasi cukup dan 1 siswa (5\%) berada pada kualifikasi gagal. Siswa yang mendapat kualifikasi sangat baik merupakan siswa yang mendapat nilai tertinggi, seluruh soal dikerjakan dengan sangat baik sehingga indikator yang ditetapkan telah dipahami oleh siswa. Siswa pada kualifikasi baik merupakan siswa yang masih keliru dalam menyebutkan karakteristik indikator dan masih kurang detail dalam menjabarkan proses penyelesaian. Sementara siswa yang berada pada kualifikasi cukup merupakan siswa yang masih lemah dalam mendefinisikan indikator, masih lemah dalam menghitung dan soal-soal essay dikerjakan tetapi tidak detail. Sementara siswa yang berada pada kualifikasi gagal merupakan siswa yang gagal dalam mendefiniskan indikator, salah menghitung dan soal-soal essay yang dikerjakan tidak sempurna.

\section{Deskripsi Hasil Nilai Akhir}

Terdapat tiga tujuan pembelajaran yang merupakan hasil belajar yang digolongkan menurut klasifikasi Bloom yaitu: aspek afektif, aspek psikomotor dan aspek kognitif. Oleh karena itu nilai akhir (NA) diperoleh dari nilai kognitif $(20 \%)+$ nilai afektif $(30 \%)+$ nilai psikomotor $(30 \%)+$ nilai tes formatif $(20 \%)$ akan tetapi nilai rata-rata dari keempat aspek tersebut perlu disetarakan menggunakan uji z-score. Persentase pencapaian nilai akhir siswa ditunjukkan pada Tabel 6.

Tabel 6. Persentase Pencapaian Nilai Akhir Siswa

\begin{tabular}{|l|l|l|l|}
\hline $\begin{array}{l}\text { Tingkat } \\
\text { Penguasaan }\end{array}$ & Frekuensi & $\begin{array}{l}\text { Persentase } \\
(\%)\end{array}$ & Kualifikasi \\
\hline $91-100$ & 8 & 42 & Sangat Baik \\
\hline $80-90$ & 7 & 37 & Baik \\
\hline $69-79$ & 4 & 21 & Cukup \\
\hline$<69$ & - & - & Gagal \\
\hline \multicolumn{2}{|l|}{ Rata-rata nilai akhir (NA) $=86,74$} & Baik \\
\hline
\end{tabular}

Tabel 6. Menunjukkan bahwa terdapat 8 siswa (42\%) berada pada kualifikasi sangat baik, 7 siswa (37\%) berada pada kualifikasi baik, 4 siswa (21\%) berada pada kualifikasi cukup. Rata-rata pencapaian nilai akhir siswa pada semua aspek yaitu 86,74 yang berada pada kualifikasi baik. Nilai tertinggi siswa yakni 95,76 dan nilai terendah 76,07.

\section{Analisis Hasil Tes Kemampuan Awal}

Tes awal bertujuan untuk mengetahui sejauh manakah materi atau bahan pelajaran yang akan diajarkan telah dikuasai oleh siswa (Sudijono, 2008). Tes awal terdiri dari 13 soal PG dan 2 soal essay. Sikap siswa terlihat tidak tenang atau kebingungan dengan masalah yang ada di depan mereka saat mengerjakan tes awal. Kebanyakan dari mereka yang menoleh ke teman untuk menanyakan jawaban dari soal yang diberikan pada materi rangkaian listrik. Hasil penelitian menunjukkan bahwa kemampuan awal siswa bervariasi antara siswa yang satu dengan yang lain, kebanyakan dari mereka menjawab dengan menerka jawaban pada obsen yang tersedia sedangkan pada soal essay untuk tingkatan menghitung siswa masih kesulitas dalam pengerjaan soal yang diberikan. Permasalahan tersebut diperjelas oleh Trianto (2010) yang menyatakan bahwa seorang pembelajar mengalami kesulitan dalam 
memahami suatu pengetahuan tertentu, yang salah satunya karena pengetahuan baru yang diterimanya tidak terjadi hubungan dengan pengetahuan sebelumnya, atau mungkin pengetahuan awal sebelumnya belum dimiliki.

\section{Hasil Belajar yang Diperoleh Siswa}

Hasil penelitian menunjukkan keberhasilan siswa yang terlihat pada nilai akhir siswa selama kegiatan belajar mengajar berlangsung dengan menggunakan media pembelajaran berbasis software multisim berbantuan model discovery learning secara individual dan klasikal 83\% siswa telah memperoleh hasil melampaui kriteria ketuntasan minimal yang dipersyaratkan, walaupun dengan kualifikasi yang berbeda-beda. Sisanya, satu siswa belum berhasil mencapai kriteria ketuntasan minimal. Secara keseluruhan dapat dilihat rata-rata skor pencapaian nilai akhir siswa, yaitu 86,74.

Hasil ini menunjukkan bahwa penggunaan media pembelajaran software multisim berbantuan model discovery learning efektif membantu siswa guna mencapai hasil belajar siswa. Model pembelajaran discovery learning ini menitikberatkan kepada siswa untuk mecari sendiri jawaban atas permasalahan yang diberikan sehingga sikap komunikasi antara anggota satu dengan yang lainnya harus terjalin dengan baik dan ini terbukti dengan hasil yang didapatkan yaitu seluruh respon siswa sangat baik selama kegiatan belajar mengajar berlangsung. Dalam keterampilan proses sains, semua kemampuan siswa (kognitif, afektif, dan psikomotor) berkembang dengan baik. Dalam perkembangan inilah masing-masing ranah ini memberi kontribusi yang nyata dalam pembentukan hasil belajar siswa, karena masing-masing ranah tercapai dalam kualifikasi baik sampai sangat baik, maka akan memberi kontribusi yang baik pula pada nilai akhir. Purwanto (2014) menyatakan bahwa hasil belajar merupakan perolehan dari proses belajar siswa sesuai degan tujuan pengajaran. Dengan demikian, keberhasilan ini tidak terlepas dari pemahaman siswa pada materi yang diajarkan.

Selama proses belajar mengajar menggunakan media berbasis software multisim, terlihat bahwa siswa lebih aktif karena materi rangkaian listrik menjadi kelihatan lebih menarik dan siswa lebih mudah untuk menyelesaikan soal pada LKS dan tes formatif. Penggunaan media pembelajaran berbasis software multisim sangat berpengaruh untuk mencapai hasil belajar siswa, kemampuan kognitif, mengembangkan sejumlah keterampilan, membangun hubungan sosial antara siswa, mampu menjelaskan persoalan pendapat lewat diskusi dan kerja kelompok, serta berani menyampaikan pendapat. Hal ini seperti dikemukakan Hamalik (2009) bahwa hasil belajar adalah perubahan tingkah laku pada aspek-aspek tertentu, misalnya pengetahuan, pemahaman, kebiasaan, keterampilan, apresiasi, emosional, hubungan sosial, budi pekerti (etika), sikap dan lainya. Hasil belajar adalah perubahan yang didasari oleh pengetahuan yang telah dimiliki sebelumnya dan pengetahuan baru itu juga menjadi dasar yang diperoleh untuk pengetahuan berikutnya yang lebih kompleks (Kosasih, 2014).

\section{Kesimpulan}

Berdasarkan hasil penelitian dan pemba- hasannya, maka penulis dapat menyimpulkan bahwa Penggunaan media pembelajaran berbasis software multisim berbantuan model discovery learning efektif membantu siswa kelas IX SMP Negeri 11 ambon guna mencapai hasil belajar fisika materi rangkaian listrik. Hal ini ditunjukkan dengan rata-rata skor pencapaian nilai akhir siswa 86,74 dan berada pada kualifikasi baik. Respon siswa selama kegiatan belajar mengajar berlangsung termasuk dalam kategori sangat baik ditunjukkan pada perolehan nilai aspek afektif siswa yang berada pada kategori sangat baik.

\section{Ucapan Terima Kasih}

Penelitian ini merupakan penelitian kolaborasi yang dibiayai oleh Fakultas Keguruan dan Ilmu Pendidikan Universitas Pattimura. Penulis mengucapkan terima kasih kepada Pimpinan Fakultas untuk pendanaan tersebut. Penulis juga mengucapkan terima kasih kepada Kepala SMA Negeri 11 Ambon atas kerja sama, sehingga menjamin terlaksananya penelitian ini.

\section{Daftar Pustaka}

Arikunto, S. 2009. Dasar-dasar Evaluasi Pendidikan. Jakarta: Rineka Cipta. Arsyad, A. 2007. Media Pembelajaran. Jakarta: Raja Grafindo. Hamalik, O. 2009. Proses Belajar Mengajar. Jakarta: Bumi Aksara. Kosasih, E. 2014. Strategi Belajar dan Pembelajaran Implementasi Kurikulum 2013. Bandung: Yrama Widya. 
Lubis, Grafura. 2012. Penelitian Tindakan Kelas. Jakarta: Prenada Media Group. Purwanto. 2014. Evaluasi Hasil Belajar. Yogyakarta: Pustaka Pelajar.

Sadiman, A.S. 2007. Media Pendidikan, Pengertian, Pengembangan, dan Pemanfaatannya. Jakarta: Rajawali Press.

Shema. 2004. Multisim National Instruments Circuit Design. Jakarta: Venus VT.

Sudijono, A. 2008. Pengantar Statistik Pendidikan. Jakarta: RajaGrafindo Persada.

Trianto. 2010. Mendesain Model Pembelajaran Inovatif-Progresif. Jakarta: Prenada Media Group.

Wenno, I.H. 2011. Metodologi Pembelajaran Sains Berbasis Konteks. Yogyakarta: Grafika Indah. 